\title{
Heads I Win, Tails You Lose: Institutional Monitoring on Executive Pay Rigidity
}

\author{
Paul Moon Sub Choi \\ Ewha Womans University, Korea \\ Chune Young Chung \\ Chung-Ang University, Korea \\ JiHoon Hwang \\ University of Arizona \\ Chang Liu \\ California State University, Sacramento
}

\begin{abstract}
Agency theory argues that pay for performance alleviates the conflict of interest between managers and shareholders. Furthermore, the literature finds that institutional monitoring tends to promote the performance-pay linkage, thus aligning the two parties' incentives. We find that executive compensation rigidity is negatively and significantly associated with firm value. Moreover, ownership by long-term institutional investors reduces the pay rigidity of top managers in underperforming firms, thus decreasing the value-destroying effect of the rigidity. Overall, these results reaffirm the role of institutional monitoring in mitigating managerial rent extraction. JEL Classification: G23, G34, J33, M41
\end{abstract}




\section{Acknowledgements}

Chung (correspondence) can be contacted at bizfinance@cau.ac.kr; School of Business Administration, Chung-Ang University, 84 Heukseok-ro, Dongjak-gu, Seoul 06974, Korea; tel.: $+82-2-820-5544$. Special thanks are due to William Elliott (the Editor) and an anonymous referee. We also thank Warren Bailey, Lucian A. Bebchuk, Joung Hwa Choi, Ji-Woong Chung, Yaniv Grinstein, Byoung-Hyoun Hwang, Rajkamal Iyer, Andrew Karolyi, Hyunseob Kim, Y. Han (Andy) Kim, Jaehoon Lee, Bala Maniam, Jiangang Peng, and seminar participants at Hunan University (Changsha, Hunan, China), ISESS 2018 (Okinawa, Japan), and RICBFM 2019 (Kota Kinabalu, Malaysia). Part of this research was conducted while Choi was a visiting scholar at the Samuel Curtis Johnson Graduate School of Management, Cornell University, funded by the grant provided by the Fulbright Scholarship Program. This work was supported by the Ministry of Education of the Republic of Korea and the National Research Foundation of Korea (NRF2018S1A5A2A01029148). The authors contributed equally to this work. Standard disclaimer rules apply, and all errors are our own. 


\title{
Heads I Win, Tails You Lose: Institutional Monitoring on Executive Pay Rigidity
}

\begin{abstract}
Agency theory argues that pay for performance alleviates the conflict of interest between managers and shareholders. Furthermore, the literature finds that institutional monitoring tends to promote the performance-pay linkage, thus aligning the two parties' incentives. We find that executive compensation rigidity is negatively and significantly associated with firm value. Moreover, ownership by long-term institutional investors reduces the pay rigidity of top managers in underperforming firms, thus decreasing the value-destroying effect of the rigidity. Overall, these results reaffirm the role of institutional monitoring in mitigating managerial rent extraction.

JEL Classification: G23, G34, J33, M41
\end{abstract}




\section{Introduction}

Incentive compensation has long been a pivotal internal governance mechanism. Compensation policies that closely tie managerial emoluments to firm performance are deemed effective schemes that align the interests of corporate executives and outside shareholders, thus reducing agency costs (Core, Holthausen, and Larcker 1999; Grossman and Hart 1983; Hölmstrom 1979; Jensen and Meckling 1976; Jensen and Murphy 1990; Murphy 1999). However, performance-related pay is called into question when managers receive increasingly outsized compensation packages that are not justified by the growth of their firms (Crystal 1991; Blanchard, Lopez-de-Silanes, and Shleifer 1994; Bebchuk and Grinstein 2005). Moreover, the problem is exacerbated by the downward rigidity of pay-for-performance sensitivity (PPS), known as "pay without performance," which implies that executive compensation does not diminish proportionally following poor firm performance (Garvey and Milbourn 2006; Gaver and Gaver 1998; Shaw and Zhang 2010). Some studies argue that the reduced PPS and pay without performance arise from the proclivity of top managers for rent extraction and directors' inability to engage in arm's length negotiations with managers over chief executive officer (CEO) compensation (Bebchuk, Fried, and Walker 2002; Bebchuk and Fried 2004). In a weakly governed firm, executives tend to receive non-performancebased pay, and incentive-based pay (e.g., stock options) is more likely to be timed opportunistically (e.g., Core, Holthausen, and Larcker 1999; Bertrand and Mullainathan 2001; Yermack 1997; Bebchuk, Grinstein, and Peyer 2010). In this article, we investigate whether institutional investors can ameliorate the suboptimal executive pay structures observed in corporate America and how these institutions are associated with shareholder value.

The prominent role of institutional investors in corporate governance has been well documented in the literature as their ownership of U.S. equities has increased steadily over time. 
Shleifer and Vishny (1986) contend that large equity stakes held by institutional investors allow them to engage in shareholder activism, which provides sufficient benefits to overcome the associated costs. Extending this theoretical work, numerous empirical studies suggest that institutional investors can effect positive changes in corporate policies and internal governance structures (e.g., Chen, Harford, and Li 2007; Appel, Gormley, and Keim 2016; Liu, Chung, Sul, and Wang 2018; Harford, Kesckes, and Mansi 2018). Not surprisingly, the role of executive compensation as a major incentive-aligning scheme has been scrutinized closely. Evidence suggests that institutional investors not only prefer certain compensation structures, but also actively influence pay levels, PPS, and the pay-setting process through channels such as increasing the independence of the board compensation committee and sponsoring "say-on-pay" proxy campaigns (e.g., Hartzell and Starks 2003; Almazan, Hartzell, and Starks 2005; Chowdhury and Wang 2009; Ertimur, Ferri, and Muslu 2011; Ozkan 2011; Shin and Seo 2011). Improved pay structures lead to higher shareholder value and better firm performance.

However, a notable gap in the literature is the limited attention paid to the asymmetric nature of PPS. On the one hand, high PPS is not necessarily associated with improved shareholder value, particularly if shareholders are disproportionately burdened with excessive executive compensation or if executives' pay responds as much to lucky market movements as it does to performance attributable to managerial success (Bertrand and Mullainathan 2001; Blanchard, Lopez-de-Silanes, and Shleifer 1994). On the other hand, when executives reap upside benefits from stellar performance, but are immune to downside operational losses, they tend to take unnecessary risks at the expense of shareholder value. In this study, we fill this void in the literature by adopting a new framework that specifically addresses downward executive compensation rigidity (ECR). 
We first corroborate the evidence on the existence of ECR and test whether it negatively affects shareholder value. Then, we examine whether institutional monitoring constrains downward-rigid pay arrangements and how this affects shareholder wealth. Our analysis is based on a sample of 11,294 firm-year observations of U.S. firms from 1995 to 2012. The empirical findings are as follows. First, executive pay is more responsive when firms experience earnings increases versus decreases, which exemplifies the existence of ECR. Second, ECR undermines shareholder value, suggesting that downward-rigid compensation arrangements fail to incentivize executives to act in the best interests of shareholders. Third, a higher level of monitoring by institutions, measured by their ownership stake in a firm, reduces ECR and its negative effects on firm value. In particular, we show that institutions with long-term horizons and large shareholdings are effective in monitoring ECR and mitigating its adverse effects.

Overall, we provide new evidence on the monitoring role of institutional investors by examining the interplay between ECR, institutional ownership, and firm value. Our contributions to the literature are threefold. First, we substantiate the asymmetric, downward-rigid link between pay and performance (i.e., ECR) and confirm its value-destroying effect. Owing to the limited attention paid to ECR, few prior studies empirically differentiate between negative and positive PPS. In addition, the literature does not provide a consistent explanation for the existence of ECR. For example, Leone, Wu, and Zimmerman (2006) assume that a board has sufficient discretion when determining CEO pay and assert that cash compensation for CEOs is more sensitive to negative stock returns than it is to positive stock returns. With regard to the findings of Leone, $\mathrm{Wu}$, and Zimmerman, Dechow (2006) indicates that managerial influence may drive the determination of executive pay. Garvey and Milbourn (2006), Gaver and Gaver (1998), and Shaw and Zhang (2010) also report a downward rigidity of CEO compensation and imply that the agency problem 
may affect CEO pay, largely in favor of executives. ${ }^{1}$ Here, we examine the effect of an accounting-based performance measure (change in return on assets [ROA]) on total CEO compensation and present empirical evidence that the substantial influence of executives over the board in terms of setting pay engenders ECR. Thus, we contribute to the literature by showing the negative relation between ECR and firm value, confirming that the agency problem leads to ECR.

Second, we identify the role of institutional investors in reducing the agency costs associated with ECR. In this case, our study is closely related to the literature (e.g., Shin and Seo 2011) in that we link institutional ownership to executive compensation and focus on the heterogeneity of institutional investors. However, several key differences remain. Shin and Seo (2011) do not examine asymmetry in PPS, which is necessary to provide a more nuanced view of the source of managerial opportunism in compensation. In addition, we believe that our classification of institutional heterogeneity based on an investment horizon is more relevant in determining institutional investors' incentives to monitor. In particular, Shin and Seo examine public pension funds and mutual funds separately, finding that ownership by the former is negatively associated with CEO PPS. They attribute this to a pension fund's fiduciary duty to invest prudently and to the concern that high PPS leads to greater risk taking (possibly excessively) by the CEO. However, this concern should be less significant when institutional investors can mitigate the downward rigidity of executive compensation, which Shin and Seo do not account for. This is because CEOs should be more cautious when their pay may suffer if the firm becomes distressed. Last, we extend the sample in Shin and Seo to provide updated evidence of institutional monitoring in the post-

\footnotetext{
${ }^{1}$ Shue and Townsend (2017) present an alternative and complementary explanation for the excessive rise in CEO compensation. They find empirical evidence that the rigidity in the number of options granted to executives contributes to the existence of ECR. When stock prices rise rapidly, the number rigidity engenders fast growth in the value of the options granted. Shue and Townsend further note that this number rigidity may arise from cognitive biases or a lack of sophistication in valuing options.
} 
Sarbanes-Oxley period, which is characterized by heightened awareness and a more favorable environment in which shareholders can engage in corporate governance.

Third, we elaborate on our research by showing that institutional investors with a longterm horizon are more likely to engage in active monitoring and, thus, constrain the downward rigidity of CEO compensation. Bushee (2001) asserts that "dedicated" institutions with large stakes in investee firms and a low turnover (i.e., a long-term horizon) are less focused on short-term results and pay greater attention to future firm value. This incentivizes such institutions to monitor and influence managers to improve their firms' corporate governance. We find empirical evidence that institutions with long-term horizons mitigate ECR and its adverse effect on firm value.

\section{Theory and Hypotheses}

Rooted in agency theory, the optimal contracting hypothesis posits that executive compensation should stem from firm performance to incentivize top managers to maximize shareholder value (Abowd 1990; Core, Holthausen, and Larcker 1999; Grossman and Hart 1983; Hölmstrom 1979; Jensen and Meckling 1976; Jensen and Murphy 1990; McConaughy and Mishra 1996; Murphy 1999). Consistent with this conjecture, many studies present evidence that firms pursue optimal compensation contracts that are closely tied to their own and their rival's performance (Core and Guay 1999; Aggarwal and Samwick 1999). Moreover, these performance-related contracts motivate executives to make strategic changes and to improve their firms' corporate social responsibility, which ultimately lead to improved market performance (Abowd 1990; McConaughy and Mishra 1996; Carpenter 2000; Deckop, Merriman, and Gupta 2006).

Although the optimal contracting hypothesis assumes arm's length bargaining between the board of directors and a firm's executives in the pay-setting process, Crystal (1991) and Monks and Minow (2008) argue that top managers can effectively manipulate the board's role in 
determining executive pay. For instance, entrenched CEOs usually appoint friendly compensation committee members who are loyal to the CEO, rather than to the shareholders. In this regard, the managerial power hypothesis predicts that pay schemes are the direct outcome of, rather than the solution to, the agency problem and executive rent extraction (Bebchuk, Fried, and Walker 2002; Bebchuk and Fried 2003, 2004; Bertrand and Mullainathan 2001). In this context, Bebchuk and Grinstein (2005) and Bertrand and Mullainathan (2001) present evidence that executive pay increases far beyond industry-adjusted firm growth and that it increases as the result of favorable market movements ("pay for luck") as much as it does from firm-specific performance ("pay for performance"). Additionally, Yermack (1997) and Bebchuk, Grinstein, and Peyer (2010) show that incentive options are usually granted opportunistically to allow profitable exercises for executives. Shin (2013) shows that powerful CEOs affect the pay-setting process and exploit peer benchmarking.

Downward ECR, or pay without performance, is defined as the degree to which executive pay is less sensitive to a decrease in firm performance than it is to an increase. When executives are rewarded for good firm performance, but are shielded from punishment when the firm underperforms, they have an incentive to take unnecessary risks at the expense of shareholders (i.e., "gambling with other people's money"). Despite this possibility of alarming consequences, there is a lack of research on ECR. A few accounting studies focus on the cash component of CEO compensation, finding mixed evidence on cash ECR. For example, Leone, Wu, and Zimmerman (2006) show that CEO cash compensation is actually more sensitive to negative stock returns than to positive stock returns, which they rationalize in terms of the efficient ex post settling up of CEO pay. In contrast, both Gaver and Gaver (1998) and Shaw and Zhang (2010) find evidence of rigid CEO cash compensation when a firm experiences a loss in earnings. In the finance field, Garvey 
and Milbourn (2006) link CEO pay to market movements and show that CEOs lose less pay from bad luck than they gain from good luck. Bettis et al. (2018) assert that the recent rise in the use of performance-vesting provisions in equity-based executive compensation is crucial to aligning managerial incentives with shareholders' interests. Note that we do not argue that optimal PPS is symmetric, because a certain degree of downside protection of executive compensation may serve as a retention device for talented managers and/or encourage risk taking by inherently risk-averse executives. ${ }^{2}$ However, we expect that excessively downward-rigid pay results from managerial rent seeking and undermines shareholder value. Thus, we hypothesize as follows:

\section{H1: Higher rigidity of executive pay leads to lower stock price performance.}

More important, we clarify the role of institutional investors in monitoring and constraining distorted executive incentive arrangements. In most public corporations, the board of directors is responsible for determining the compensation of the CEO and other top executives. Typically, the board adopts a multiyear compensation program that includes an option plan that limits the total amount of stock-based rewards that can be provided to senior executives and lower level employees. However, Bebchuk, Fried, and Walker (2002) point out that powerful CEOs at the helm of modern corporations make arms' length bargaining difficult for the board and likely render executive compensation contracts suboptimal. In this context, large external shareholders, such as institutional investors, are expected to help control errant managerial behavior (Huddart 1993; Shleifer and Vishny 1986). For example, Chen, Harford, and Li (2007) find that independent longterm institutions with large holdings are effective in monitoring corporate mergers. Chung and Wang (2014) and Chung et al. (2015) show that monitoring by institutional investors is positively

\footnotetext{
${ }^{2}$ To the extent that executives are paid with stock options, they are already protected from the downside. Murphy (2013) shows that more than half of the total compensation for a typical S\&P 500 CEO was accounted for by options in 2000.
} 
associated with a sound capital structure, engendering strong firm performance. Gillan and Starks (2000) and Karpoff (2001), among others, document the success of active institutions in effecting positive changes through shareholder proxy votes. With respect to executive compensation, Almazan, Hartzell, and Starks (2005) and Hartzell and Starks (2003) show that institutional ownership is positively associated with PPS and that it mitigates the agency problem between shareholders and management.

Institutional investors can reduce downward ECR via various channels. For example, they can submit shareholder proposals at annual shareholder meetings that aim to improve executive compensation plans, nominate more independent directors to the board, or remove interlocking directors and limit CEO-chairman duality (Bebchuk 2003; Ertimur, Ferri, and Oesch 2013; Gillian and Starks 2000; Smith 1996). ${ }^{3}$ Accordingly, we expect institutional ownership to affect the paysetting process in favor of shareholders (Albuquerque, Carter, and Lynch 2015; Alissa 2015; Cai and Walking 2011; Conyon and Sadler 2010; Ferri and Maber 2013; Hooghiemstra, Kuang, and Qin 2015). Thus, we hypothesize as follows:

$\mathrm{H} 2 \mathrm{a}$ : A high level of institutional ownership reduces the degree of executive pay rigidity.

We further anticipate that the active monitoring role of institutional investors in corporate governance enhances firm value. ${ }^{4}$ Increased institutional ownership likely leads to a higher risk of dismissal and to a greater threat of derivative litigation against underperforming executives. Under institutional monitoring, the board is expected to work more independently from managerial influence in terms of setting executive pay. Several studies provide evidence of an overall positive association between institutional monitoring and firm value (Burkart, Gromb, and Panunzi 1997;

\footnotetext{
${ }^{3}$ We thank the editor, William Elliott, for his comment in this regard. Further, we provide an analysis of the ECR-reducing channel via institutional investors' presence on the board of directors in Appendix C.

${ }^{4}$ Michael Siconolfi, “At Morgan Stanley, Analysts Were Urged to Soften Harsh Views," Wall Street Journal (July, 14, 1992), pp. A1, A6.
} 
Choi and Sias 2012; McConnell and Servaes 1990; Mørck, Shleifer, and Vishny 1988; Woidtke 2002). In summary, we contend that institutional monitoring should reduce the negative effect of ECR on firm value, yielding the following hypothesis:

$\mathrm{H} 2 \mathrm{~b}$ : Institutional ownership mitigates the adverse relation between pay rigidity and stock price performance.

\section{Variables, Methods, and Data}

\section{Institutional Ownership}

Following the literature, we designate a firm's level of institutional ownership, specified as the quarterly ratio of the number of shares held by institutions to the total number of shares outstanding, as a proxy for the extent of institutional monitoring. Because not all institutional investors monitor and discipline the firms they own, we decompose shareholdings into those held by monitoring and nonmonitoring institutions. Institutions with a long-term investment horizon are committed to monitoring, in which case subsequent reductions in ECR are expected to improve the firm's operational and financial performance (Chen, Harford, and Li 2007; Chung et al. 2015; Yan and Zhang 2009). Following Yan and Zhang (2009), we classify institutions with low (high) portfolio turnover as having a long-term (short-term) horizon by sorting the institutions in each quarter $t$ into terciles, based on their average portfolio turnover over the previous four quarters. The quarterly portfolio turnover (churn rate) is computed as follows:

$$
C R_{k, t}=\min \left(\text { Buy }_{k, t}, \operatorname{Sell}_{k, t}\right) /\left(\sum_{i=1}^{N_{k}} \frac{S_{k, i, t} P_{i, t}+S_{k, i, t-1} P_{i, t-1}}{2}\right),
$$

where $B u y_{k, t}$ and $S e l l_{k, t}$ are aggregate purchases and sales, respectively, by investor $k$ in quarter $t ; P_{i, t-1}$ and $P_{i, t}$ are the share prices for firm $i$ at the end of quarters $t-1$ and $t$, respectively; and $S_{k, i, t-1}$ and $S_{k, i, t}$ are the numbers of shares of company $i$ held by investor $k$ at the end of 
quarters $t-1$ and $t$, respectively. Short-term institutional ownership (SIO) denotes institutional ownership in the top quarterly portfolio turnover tercile whereas long-term institutional ownership (LIO) represents holdings by institutions in the bottom tercile.

\section{ECR and Firm Value}

In the model used to estimate PPS, we test for the asymmetric sensitivity of executive pay to corporate performance by incorporating a dummy variable to capture a decrease in the performance of a firm (equation (2) below). Following Sloan (1993) and Leone, Wu, and Zimmerman (2006), we employ ROA, defined as net income scaled by total assets at the beginning of the year, as the operating performance measure. A decrease in $R O A$ from year $t-1$ to year $t$ indicates a deterioration in performance. In equation (2), conditional on a positive and significant coefficient $\beta_{1}$, a negative and significant $\beta_{3}$ coefficient suggests pay rigidity (i.e., a smaller pay sensitivity when $R O A$ decreases):

$$
\Delta \text { Pay }_{i t}=\beta_{0}+\beta_{1} \Delta R O A_{i t}+\beta_{2} D D_{i t}+\beta_{3} \Delta R O A_{i t} \times D D_{i t}+\sum \beta_{c} \text { Controls }_{i t}+\epsilon_{i t} .
$$

Equation (2) follows Jackson, Lopez, and Reitenga (2008), in which the relation between the change in executive pay and the change in ROA is analyzed while controlling for differences in executive-specific factors between firms. Here, $\Delta P a y_{i t}$ is the natural logarithm of the ratio of total executive pay to lagged total executive pay for firm $i$ in year $t ; \Delta R O A_{i t}$ is the natural logarithm of the ratio of ROA to lagged ROA for firm $i$ in year $t$; and $D D_{i t}$ is an indicator of poor performance, which equals 1 if the ROA in year $t$ is less than that in year $t-1$, and 0 otherwise. Then, Controls $s_{i t}$ is a group of control variables, defined as follows. First, $\Delta$ Assets ${ }_{i t}$ is the natural logarithm of the ratio of the book value of assets to the lagged book value of assets for firm $i$ in year $t$. Schaefer (1998) demonstrates that a CEO's PPS may decrease with firm size, merely because the size of the relevant management team shrinks in proportion. In contrast, Jensen 
and Murphy (1990) suggest that the PPS is greater in a small firm than in a large firm. Second, $\Delta$ Sales $_{i t}$ is the natural logarithm of the ratio of sales to lagged sales for firm $i$ in year $t$. Murphy (1985) finds that executive pay is positively associated with the growth in sales, contending that previous cross-sectional studies have omitted important variables, which has strongly skewed their results. Third, $\Delta I_{-} R O A_{i t}$ is the industry average of the natural logarithm of the ratio of ROA to lagged ROA for firm $i$ in year $t$. Finally, we obtain the year and Fama and French (1997) 48industry fixed effects.

Extending Easton and Harris's (1991) specification to test Hypothesis H1, we identify empirical models that relate rigid executive pay to stock returns and to Tobin's Q (Tobin 1969). In equation (3), the effect of ECR is captured by the coefficient $\beta_{3}$, where a negative sign reflects an erosion in firm performance as a result of ECR:

$$
\text { Return }_{i t} \text { or } Q_{i t}=\beta_{0}+\beta_{1} C I_{i t}+\beta_{2} \Delta C I_{i t}+\beta_{3} \text { Rigidity }_{i t}+\epsilon_{i t} \text {, }
$$

where Return $_{i t}$ is the annualized stock return for firm $i$ in year $t ; Q_{i t}$ is industry-adjusted Tobin's Q, computed as the market value of assets divided by the book value of assets for firm $i$ in year $t ; C I_{i t}$ is comprehensive income (CI) for firm $i$ in year $t$, normalized by the stock price at the end of year $t^{-1} ; \Delta C I_{i t}$ is the ratio of CI to lagged CI for firm $i$ in year $t$, normalized by the stock price at the end of year $t^{-1}$; and Rigidity is a dummy variable equal to 1 if the timeseries coefficient estimate of the interaction term $\triangle R O A_{i t} \times D D_{i t}$ in equation (2) for firm $i$ in year $t$ is less than or equal to zero, and 0 otherwise. These key variables in our empirical tests are defined in Appendix A.

Verifying $\mathrm{H} 2 \mathrm{a}$ requires that we incorporate institutional ownership into the estimation model for ECR (equation (2)). According to a sizable body of literature, institutional ownership serves as a proxy for the intensity of institutional monitoring. For each firm-year observation, we 
obtain the most recent quarterly institutional ownership that is at least one year before the fiscal year-end when executive pay is computed. For example, for a firm observed in the fiscal year that ended in February 2010, the annual executive pay covers February 2009 to February 2010, and we obtain the corresponding institutional ownership in December 2008. ${ }^{5}$ This ensures that monitoring institutions have sufficient time to influence the executive pay structure. We expect the coefficient $\beta_{5}$ in equation (4) to be positive if pay rigidity decreases in the presence of institutional ownership, owing to the active monitoring of pay arrangements by institutional shareholders:

$$
\begin{aligned}
\Delta \text { Pay }_{i t}= & \beta_{0}+\beta_{1} \Delta R O A_{i t}+\beta_{2} D D_{i t}+\beta_{3} \Delta R O A_{i t} \times D D_{i t} \\
& +\beta_{4} I O_{i, t-1}+\beta_{5} \Delta R O A_{i t} \times D D_{i t} \times I O_{i, t-1}+\beta_{\text {etc. }} \text { Other Interaction Terms } \\
& +\sum \beta_{c} \text { Controls }_{i t}+\epsilon_{i t}
\end{aligned}
$$

where $I O_{i, t-1}$ is total institutional ownership, computed as the number of shares held by all institutions divided by the shares outstanding for firm $i$ in year $t-1$. We also use $S I O_{i, t-1}$ and $L I O_{i, t-1}$, which measure institutional ownership by short-term and long-term institutions, respectively, for firm $i$ in year $t-1$ in place of $I O_{i . t-1}$ to incorporate the heterogeneity of institutional monitoring. The remaining variables are defined in the same way as in equation (2).

Finally, testing $\mathrm{H} 2 \mathrm{~b}$ necessitates that we identify the effect of the interaction between ECR and institutional monitoring on firm value. In equation (5), institutional ownership is expected to mitigate the possible negative effect of rigid executive pay on firm value if $\beta_{3}<0$ and $\beta_{4}>0$ :

$$
\text { Return }_{i t} \text { or } Q_{i t}=\beta_{0}+\beta_{1} C I_{i t}+\beta_{2} \Delta C I_{i t}+\beta_{3} \text { Rigidity }_{i t}+\beta_{4} \text { Rigidity }_{i t} \times I O_{i, t-1}+\epsilon_{i t},
$$

where all variables are defined as above.

\section{Data and Descriptive Statistics}

${ }^{5}$ Institutions report their holdings in their $13 \mathrm{~F}$ filings every quarter. Hence, December 2008 is the most recent quarter-end one year before February 2010. 
The primary source of our executive compensation data is ExecuComp ${ }^{6}$ from which we obtain total annual salaries, bonuses, long-term incentives, stock and option grants, and other types of compensation for up to five top-level executives, with at least two consecutive years of coverage. Firm characteristics are acquired from the Center for Research in Securities Prices (CRSP) and Compustat databases. Institutional ownership data are procured from Thomson Reuters, which compiles data on quarterly institutional holdings from Form $13 \mathrm{~F}$ filings. ${ }^{7}$ We exclude all financial (Standard Industrial Classification [SIC] codes 6000-6999) and utility (SIC codes 4900-4949) firms because these industries are highly regulated. We obtain Fama and French's (1997) 48industry classifications from Kenneth French's website. ${ }^{8}$ After consolidating data from various sources, our final sample comprises 11,294 firm-year observations of S\&P 1500 firms for 19952012.

Table 1 presents descriptive statistics for the full sample. The average rate of change in total executive pay ( $\triangle$ Pay) is .063, indicating a $6.3 \%$ annual increase. Then, $\triangle R O A$ and $\triangle C I$ are negative, on average, showing that both ROA and accounting earnings decreased during the same period. These results imply that although average executive compensation has increased, average corporate earnings have deteriorated. More important, mean Rigidity captured by the timeseries regression estimate of $\triangle R O A \times D D$ is, on average, positive (.5257), revealing that performance-related pay is rigid overall. Mean total institutional ownership is $67.49 \%$, implying that institutions, on average, hold $67.49 \%$ of a firm's outstanding shares, of which long-term

${ }^{6}$ There may be a backfilling bias in the ExecuComp database that affects the magnitude of PPS estimates and, thus, the coefficients of the regressions that use these estimates (Gillan et al. 2018).

${ }^{7}$ Under Section 13F of the Securities Exchange Act of 1934, all institutional investors with US\$100 million or more under management are required to report all equity positions greater than 10,000 shares or US $\$ 200,000$ to the U.S. Securities and Exchange Commission at the end of each quarter.

${ }^{8} \mathrm{http} / / / \mathrm{mba} . t u c k . d a r t m o u t h . e d u / p a g e s /$ faculty/ken.french/Data_Library/det_49_ind_port.html 
(short-term) institutions account for 20.48\% (15.2\%). The large holdings of monitoring institutions (i.e., LIO) grant them sufficient voting rights to influence corporate decisions.

[Insert Table 1 about here.]

\section{Main Results}

Pay for Performance or Pay Without Performance and Firm Value

Examining the link between corporate performance and executive compensation, many studies employ the following proxy for PPS (Almazan, Hartzell, and Starks 2005; Hartzell and Starks 2003), which is derived as the slope coefficient $(\beta)$ of the following regression model:

$$
\Delta \text { Pay }_{i t}=\alpha+\beta \cdot \Delta \text { Shareholder Wealth } \text { it }+\epsilon_{i t},
$$

where, for firm $i, \Delta$ Pay $_{i t}$ is the change in executive pay between years $t-1$ and $t$, and $\Delta$ Shareholder Wealth $_{i t}$ is the change in shareholder wealth over the same period.

Panel A in Table 2 shows a positive correlation between changes in market capitalization and total executive pay for both increases ( $\Delta$ Market Capitalization $>0$ ) and decreases $(\Delta$ Market Capitalization $<0)$ in firm value. Panel B shows panel regressions of the change in total executive pay on the change in market capitalization. Model 1 revisits the PPS model used in the literature (equation (6)), where the estimated PPS is positive and significant $(\hat{\beta}=.1079 ; t=$ 12.61). Then, we rerun the PPS model based on the direction of the change in firm value in models 2 and 3, where the PPS estimate is positive and significant in both models. However, note that the magnitude is smaller on the downside when firm value decreases ( $\Delta$ Market Capitalization $<0$; model 3) than it is on the upside ( $\Delta$ Market Capitalization $>0$; model 2), hinting at possible asymmetry in the PPS. In model 4, we interact the change in market capitalization with a dummy variable (MC_Dummy) that indicates whether the firm value is increasing (equal to 1) or decreasing (equal to 0 ). The negative and significant coefficient estimate of the interaction term 
$\left(\Delta\right.$ Market Capitalization $\times M C_{-}$Dummy) indicates that executive pay responds asymmetrically to different realizations of firm performance: the PPS value is significantly lower when the market value of equity decreases than when it increases. This implies nonlinearity in the PPS measure with respect to firm value and indicates a bias in the positive association documented in the literature when nonlinearity is not accounted for.

[Insert Table 2 about here.]

According to traditional agency theory, a higher PPS value mitigates agency costs. However, scholars on managerial power note that the pervasive nature of downward ECR (i.e., excessive pay for executives in underperforming firms) erodes shareholder wealth (e.g., Bebchuk and Fried 2004). Accordingly, a low PPS value understates the agency problem, particularly when corporate earnings deteriorate. The downward-rigid compensation is apparent in our PPS estimates reported in Panel B of Table 2, as suggested by the negative coefficient of the interaction term in model 4 .

We define ECR, or pay without performance, as lower PPS when the firm value decreases than that when it increases. The degree of ECR reflects the magnitude of executives' rent extraction and is measured by asymmetric PPS on the downside. Table 3 summarizes the estimation results for ECR based on equation (2), where a change in executive pay is related to a change in a firm's operating performance. Here, we consider the change in a firm's operating performance (ROA) instead of the change in shareholder wealth, because shareholder wealth is highly volatile and thus not regarded as a stable gauge of executive performance. In addition, we focus on the way in which executives' direct performance is associated with their compensation contracts. Based on panel regressions by year and the Fama-French (1997) 48-industry fixed effects, and controlling for clustered standard errors (Peterson 2009), models 1 and 2 suggest that the overall compensation 
of executives in the sample firms increases with improvements in the firms' performance. Given the positive and significant coefficient estimate $\left(\beta_{1}\right)$ of the change in ROA $(\triangle R O A)$, the negative and strong coefficient of the interaction term $(\triangle R O A \times D D)$ with the "poor performance" dummy $(D D)$ corroborates the existence of pay without performance (ECR). ${ }^{9}$ The Fama-MacBeth (1973) regressions reported in models 3 and 4 provide an interpretation qualitatively equivalent to models 1 and 2. In summary, these outcomes confirm that PPS is greater for firms that perform well than for those that underperform, which exemplifies the existence of the ECR phenomenon and is consistent with findings documented in the literature (Garvey and Milbourn 2006).

[Insert Table 3 about here.]

Based on equation (3), models 1 and 2 (see Table 4) establish the value-destroying effect of ECR using panel regressions of stock returns (model 1) and industry-adjusted Tobin's Q (model 2), controlling for Petersen's (2009) robust standard errors. We find that the impacts (coefficient estimates) of ECR (Rigidity) are both economically and statistically negative, implying that pay without performance has a severe detrimental effect on shareholder wealth. This occurs regardless of whether institutional ownership is identified as being long term (monitoring) (model 2) or short term (transient) (model 1). The Fama-MacBeth (1973) regressions of stock returns and Tobin's Q with the same specifications are presented in models 3 and 4, respectively, and provide largely identical inferences. Thus, the results in Table 4 support H1.

\section{[Insert Table 4 about here.]}

\footnotetext{
${ }^{9}$ As a robustness check, we provide an alternative definition of $D D$ as a dummy variable that equals 1 if the current year's ROA is $10 \%$ or $20 \%$ lower than that of the previous year. Though unreported for brevity, we still find that PPS is greater for firms that perform well than it is for those that underperform, which is consistent with the findings in Table 3. In addition, we use the return on equity (ROE) measure instead of ROA as an additional robustness test and find qualitatively equivalent results as in Table 3. These results are available upon request.
} 
Institutional Investors, ECR, and Firm Value

If institutions actively monitor pay without performance, we can expect a negative relation between monitoring institutions' ownership and ECR. To examine this, we sort our sample firms, in ascending order, into five equally weighted quintile portfolios, based on the percentage ownership of all (IO), long-term (LIO), and short-term (SIO) institutions. Then, we compute the corresponding mean values of ECR (Rigidity) in each quintile (see Table 5).

\section{[Insert Table 5 about here.]}

Overall, we find an inverse association between all measures of institutional ownership and ECR values. The $t$-test of the difference between the ECRs of the first quintile (lowest ownership) and fifth quintile (highest) firms, sorted by $\mathrm{IO}$, is negative and significant $(t=-2.88)$. The sign and magnitude are most pronounced $(t=-3.23)$ for the difference between the ECRs of the two extreme quintiles sorted by LIO, whereas the difference between the quintiles of firms sorted by SIO is statistically insignificant. These univariate relations provide preliminary evidence in favor of Hypothesis H2a. Furthermore, they confirm the conventional wisdom in the literature that longterm institutions play an active monitoring role, whereas their short-term counterparts simply trade on their informational advantage (Chen, Harford, and Li 2007; Yan and Zhang 2009).

Based on equation (4), models 1 and 2 (shown in Table 6) show the results of multivariate regressions of the change in executive pay $(\triangle P a y)$ on all institutions (IO; model 1) and on shortterm (SIO) versus long-term (LIO) institutions (model 2). Here, we control for covariates such as year and Fama-French (1997) industry fixed effects and use Petersen's (2009) robust standard errors. Model 1 shows a positive and significant $\left(\hat{\beta}_{1}\right)$ coefficient estimate for the change in corporate earnings $(\triangle R O A)$, as well as a negative and significant $\left(\hat{\beta}_{3}\right)$ coefficient estimate for the interaction of the change in earnings and the "poor performance" dummy $(\triangle R O A \times D D)$. 
Therefore, a positive and significant sign for the coefficient $\left(\hat{\beta}_{5}\right)$ of the three-way interaction term $(\triangle R O A \times D D \times I O)$ indicates that an increase in institutional holdings $(I O)$ mitigates ECR significantly. As suggested in the univariate tests shown in Table 5, model 2 confirms the effective monitoring of long-term institutions ( $L I O)$, with a positive and significant coefficient estimate of the three-way interaction term reflecting the ownership of long-term institutional investors $(\triangle R O A \times D D \times L I O)$. However, the coefficient estimate of the interaction term for SIO $(\triangle R O A \times D D \times S I O)$ appears to be statistically insignificant. In other words, executive pay is less rigid in firms with a higher level of institutional ownership (particularly long-term ownership), confirming that long-term institutional shareholders play active monitoring and advisory roles in setting compensation arrangements. The Fama-MacBeth (1973) counterparts of models 1 and 2, reported in models 3 and 4, respectively, lead to largely unchanged inferences. Although many previous studies cite a positive association between PPS and monitoring as evidence of lower agency costs (Almazan, Hartzell, and Starks 2005; Hartzell and Starks 2003; Hwang and Kim 2009; Ozkan 2011), their findings are likely to be biased on the downside of a change in corporate earnings. The implication of our asymmetric measure of PPS suggests that institutional monitoring is effective in constraining the downward-rigid compensation of top managers in firms that show disappointing performance. ${ }^{10}$

[Insert Table 6 about here.]

Turning to Hypothesis $\mathrm{H} 2 \mathrm{~b}$, we examine how firm value is affected by institutional monitoring and ECR. Using various measures of institutional ownership (IO, SIO, and LIO) as proxies for the degree of institutional monitoring, we extend the results in Table 4 on the negative

\footnotetext{
${ }^{10}$ We replicate Table 6 using ROE instead ROA as a robustness check and find qualitatively equivalent results, available upon request.
} 
association between executive pay rigidity and firm value by interacting institutional ownership with our measure of ECR (Rigidity). ${ }^{11}$ The estimates of multiple models based on equation (5) are presented in Table 7. Specifically, models 1-4 are panel regressions, with Petersen's (2009) robust standard errors of stock returns (models 1 and 3) and industry-adjusted Tobin's Q (models 2 and 4), on ECR and the interaction of ECR with institutional monitoring. Our estimates reveal the following findings. First, the detrimental impact of pay without performance on firm value is evident in terms of the magnitude and significance of the negative coefficient estimate of Rigidity $\left(\hat{\beta}_{3}<0\right)$, regardless of whether we focus on total institutional ownership (IO; models 1 and 2) or distinguish between SIO and LIO (models 3 and 4). Second, and more important, for Hypothesis $\mathrm{H} 2 \mathrm{~b}$, we find that larger institutional holdings, particularly those owned by long-term monitoring institutions (i.e., LIO), alleviate the value-destroying effect of downward ECR, as

${ }^{11}$ We adopt this new approach because we cannot estimate firm-level rigidity each year based on the crosssectional regression approach in equation (2), which is commonly used in the literature. Here, the time-series approach allows us to overcome the restriction on measuring firm-level rigidity. However, this approach could be subject to a look-ahead bias if the estimated firm-level rigidity is used in the cross-sectional/panel analysis, as in equation (5). Hence, as a robustness check, we estimate rigidity based on past observations so that institutional investors can obtain the information they require before monitoring the rigidity. Because the time-series regression approach requires sufficient observations for each firm to estimate the rigidity coefficient, we restrict the sample to firms with at least 15 observations. This leads to the estimation period 1995-2009 for the rigidity measure. We examine the effect of institutional investors on firm value subject to the degree of lagged compensation rigidity during 2010-2012. Because the investigation period is only three years (which limits the use of the Fama-MacBeth, 1973, regression approach), we consider only a panel regression estimation adjusted for robust clustering (Petersen 2009). We find that the negative relations between the rigidity dummy and firm value are still significant, corroborating the negative effect of ECR on firm value. More important, the coefficients for the interaction term between the institutional monitoring measure and the rigidity dummy are positive and significant in all models. These findings are largely consistent with Hypothesis H2a. Hence, we believe our results are not materially affected by a look-ahead bias. The results are available upon request. 
suggested by the positive and significant coefficients of the interaction terms Rigidity $\times I O$ and Rigidity $\times L I O$ observed in all models.

[Insert Table 7 about here.]

Models 5-8 of Table 7 are similar, estimated using the Fama-MacBeth (1973) method, and largely corroborate the evidence shown in models $1-4 .^{12}$ Our results on the beneficial effect of long-term institutional investors substantiate the positive association between committed institutional monitoring and firm value. We extend our claims further by highlighting the role of active monitoring by long-term institutional shareholders in mitigating the wealth-undermining ECR. In Appendix B, we provide robustness tests based on alternative measures of institutional monitoring and find that the results are consistent with the findings shown in Tables 6 and 7. Overall, the outcomes presented in Table 7 support Hypothesis H2b.

\section{Conclusion}

The literature suggests that institutional monitoring is positively associated with the sensitivity of executive pay to firm performance (Almazan, Hartzell, and Starks 2005; Hartzell and Starks 2003; Shin and Seo 2011). Here, we extend this finding to address the persistent phenomenon of rigid executive pay when a firm underperforms, which biases the conventional PPS measure. As such, we posit that active monitoring by institutional shareholders in the presence of suboptimal compensation contracts mitigates the damaging effect of rigid pay arrangements on shareholder wealth. Our empirical findings are as follows. First, ECR is negatively and significantly associated

${ }^{12}$ Our findings might be altered by not controlling for CEO turnover, because CEO compensation is materially affected in a year when a CEO turnover occurs, which dilutes the measure of compensation rigidity. As a robustness check, we reestimate our main hypothesis based on a sample that excludes firm-year observations with CEO turnovers. The results remain consistent. Though unreported for brevity, the results are available upon request. 
with firm value, measured by stock returns and Tobin's Q. In other words, downward-rigid pay arrangements are detrimental to shareholder wealth. Second, we find that a higher level of institutional ownership induces lower ECR, indicating that institutional shareholders, particularly those with a long-term investment horizon, play an active monitoring role that constrains the valuedestroying effects of rigid pay schemes. These important conclusions are robust to alternative measures of institutional ownership. Collectively, our results lend empirical support to the active monitoring hypothesis.

Although our findings are consistent with the role of institutional monitoring in curbing executives' rent extraction, we acknowledge the following caveats. First, executive compensation is part of the overall incentive-alignment mechanism between firms and managers and, thus, may not fully reflect the extent of performance-driven rewards and punishment. For example, the board of directors can replace executives rather than reduce their pecuniary compensation when firms report substantially poor performance. In addition, curtailing executive compensation may decrease managerial morale, causing talented managers to depart. Hence, future research should investigate the optimal level of PPS and ECR. Second, we use the coefficient of change in pay, scaled by ROA, as a measure of pay rigidity. Because a large component of pay is stock and stock options, the pay level and change in pay vary as a function of stock returns and accounting performance (e.g., Leone, Wu, and Zimmerman 2006). By omitting stock returns, our results may underestimate PPS. Third, because we study the effect of pay rigidity on firm performance (stock returns and Tobin's Q), the causal interpretation that pay rigidity destroys value may require further endogeneity tests. For example, we have not controlled for marketwide covariates, such as market size (SMB) and value (HML) premium factors (Fama and French 1993). Similarly, variables related to board structure and/or CEO skills are not included. Finally, the components of 
pay may vary in terms of their sensitivity to performance (Garvey and Milbourn 2006; Leone, Wu, and Zimmerman 2006). We leave these questions to future studies.

\section{References}

Abowd, J. M., 1990, Does performance-based managerial compensation affect corporate performance? Industrial and Labor Relations Review 43, 52-73.

Aggarwal, R., and A. A. Samwick, 1999, Executive compensation, strategic competition and relative performance evaluation: Theory and evidence, Journal of Finance 54, 1999-2043.

Albuquerque, A. M., M. E. Carter, and L. J. Lynch, 2015, Court intervention as a governance mechanism over CEO pay: Evidence from the Citigroup derivative lawsuit, European Accounting Review 24, 637-58.

Alissa, W., 2015, Boards' response to shareholders' dissatisfaction: The case of shareholders' say on pay in the UK, European Accounting Review 24, 727-52.

Almazan, A., J. C. Hartzell, and L. T. Starks, 2005, Active institutional shareholders and cost of monitoring: Evidence from executive compensation, Financial Management 34, 5-34.

Appel, I., T. Gormley, and D. Keim, 2016, Passive investors, not passive owners, Journal of Financial Economics 121, 111-41.

Bebchuk, L. A., 2003, The case for shareholder access to the ballot, The Business Lawyer 59, 4366.

Bebchuk, L. A., and J. M. Fried, 2003, Executive compensation as an agency problem, Journal of Economic Perspectives 17, 71-92. 
Bebchuk, L. A., and J. M. Fried, 2004, Pay without performance: The unfulfilled promise of executive compensation, Boalt Working Papers in Public Law, University of California, Berkeley.

Bebchuk, L. A., J. M. Fried, and D. J. Walker, 2002, Managerial power and rent extraction in the design of executive compensation, University of Chicago Law Review 69, 751-846.

Bebchuk, L. A., and Y. Grinstein, 2005, The growth of executive pay, Oxford Review of Economic Policy 21, 283-303.

Bebchuk, L. A., Y. Grinstein, and U. Peyer, 2010, Lucky CEOs and lucky directors, Journal of Finance 65, 2363-401.

Becht, M., J. Franks, C. Mayer, and S. Rossi, 2009, Returns to shareholder activism. Evidence from a clinical study of the Hermes UK Focus Fund, Review of Financial Studies 22, 3093129.

Bertrand, M., and S. Mullainathan, 2001, Are CEOs rewarded for luck? The ones without principals are, Quarterly Journal of Economics 116, 901-32.

Bettis, J. C., J. M. Bizjak, J. L. Coles, and S. L. Kalpathy, 2018, Performance-vesting provisions in executive compensation, Journal of Accounting and Economics 66. 194-221.

Blanchard, O. J., F. Lopez-de-Silanes, and A. Shleifer, 1994, What do firms do with cash windfalls? Journal of Financial Economics 36, 337-60.

Burkart, M., D. Gromb, and F. Panunzi, 1997, Large shareholders, monitoring, and the value of the firm, Quarterly Journal of Economics 112, 693-728.

Bushee, B. J., 2001, Do institutional investors prefer near-term earnings over long-run value? Contemporary Accounting Research 18, 207-46. 
Cai, J., and R. A. Walking, 2011, Shareholders' say on pay: Does it create value? Journal of Financial and Quantitative Analysis 46, 299-339.

Carleton, W. T., J. M. Nelson, and M. S. Weisbach, 1998, The influence of institutions on corporate governance through private negotiations: Evidence from TIAA-CREF, Journal of Finance $53,1335-62$.

Carpenter, M., 2000, The price of change: The role of CEO compensation in strategic variation and deviation from industry strategy norms, Journal of Management 26, 1179-98.

Chen, X., J. Harford, and K. Li, 2007, Monitoring: Which institutions matter? Journal of Financial Economics 86, 279-305.

Choi, N., and R. Sias, 2012, Why does financial strength forecast stock returns? Evidence from subsequent demand by institutional investors, Review of Financial Studies 25, 1550-87.

Chowdhury, S., and E. Z. Wang, 2009, Institutional activism types and CEO compensation: A time-series analysis of large Canadian corporations, Journal of Management 35, 5-36.

Chung, C. Y., and K. Wang, 2014, Do institutional investors monitor management? Evidence from the relationship between institutional ownership and capital structure, North American Journal of Economics and Finance 30, 203-33.

Chung, C. Y., C. Liu, K. Wang, and B. Zykaj, 2015, Institutional monitoring: Evidence from Fscore, Journal of Business Finance and Accounting 42, 885-914.

Conyon, M., and G. Sadler, 2010, Shareholder voting and directors' remuneration report legislation: Say on pay in the UK, Corporate Governance: An International Review 18, 296-312.

Core, J., and W. Guay, 1999, The use of equity grants to manage optimal equity incentive levels, Journal of Accounting and Economics 28, 151-84. 
Core, J. E., R. W. Holthausen, and D. F. Larcker, 1999, Corporate governance, chief executive officer compensation, and firm performance, Journal of Financial Economics 51, 371-406.

Crystal, G. S., 1991, In Search of Excess: The Overcompensation of American Executives (W.W. Norton, New York).

DeAngelo, H. and L. DeAngelo, 1989, Proxy contests and the governance of publicly held corporations, Journal of Financial Economics 23, 29-59.

Dechow, P. M., 2006, Asymmetric sensitivity of CEO cash compensation to stock returns: A discussion, Journal of Accounting and Economics 42, 193-202.

Deckop, J., K. Merriman, and S. Gupta, 2006, The effects of CEO pay structure on corporate social performance, Journal of Management 32, 329-42.

Easton, P., and T. Harris, 1991, Earnings as an explanatory variable for returns, Journal of Accounting Research 29, 19-36.

Easton, P., and J. Pae, 2004, Accounting conservatism and the relation between returns and accounting data, Review of Accounting Studies 9, 495-521.

Ertimur, Y., F. Ferri, and V. Muslu, 2011, Shareholder activism and CEO pay, Review of Financial Studies 24, 535-92.

Ertimur, Y., F. Ferri, and D. Oesch, 2013, Shareholder votes and proxy advisors: Evidence from say on pay, Journal of Accounting Research 51, 951-96.

Fama, E. F., and K. R. French, 1993, Common risk factors in the returns on stocks and bonds, Journal of Financial Economics 33, 3-56.

Fama, E. F., and K. R. French, 1997, Industry costs of equity, Journal of Financial Economics 43, 153-93. 
Fama, E. F., and J. MacBeth, 1973, Risk, return, and equilibrium: Empirical tests, Journal of Political Economy 81, 607-36.

Ferri, F., and D. A. Maber, 2013, Say on pay votes and CEO compensation: Evidence from the UK, Review of Finance 17, 527-63.

Garvey, G. M., and T. T. Milbourn, 2006, Asymmetric benchmarking in compensation: Executives are rewarded for good luck but not penalized for bad, Journal of Financial Economics 82, $197-225$.

Gaver, J. G., and K. M. Gaver, 1998, The relation between nonrecurring accounting transactions and CEO cash compensation, Accounting Review 73, 235-53.

Gillan, S., J. C. Hartzell, A. Koch, and L. T. Starks, 2018, Getting the incentives right: Backfilling and biases in executive compensation data, Review of Financial Studies 31, 1460-98.

Gillan, S. L., and L. T. Starks, 2000, Corporate governance proposals and shareholder activism: The role of institutional investors, Journal of Financial Economics 57, 275-305.

Grossman, S. J., and O. D. Hart, 1983, An analysis of the principal-agent problem, Econometrica $51,7-45$.

Hadlock, C. J., and M. Schwartz-Ziv, 2018, Blockholder heterogeneity, multiple blocks, and the dance between blockholders, Unpublished manuscript.

Harford, J., A. Kesckes, and S. Mansi, 2018, Do long-term investors improve corporate decision making? Journal of Corporate Finance 50, 424-52.

Hartzell, J. C., and L. T. Starks, 2003, Institutional investors and executive compensation, Journal of Finance 58, 2351-74.

Hölmstrom, B., 1979, Moral hazard and observability, Bell Journal of Economics 10, 74-91. 
Hooghiemstra, R., Y. F. Kuang, and B. Qin, 2015, Say-on-pay votes: The role of the media, European Accounting Review 24, 753-78.

Huddart, S., 1993, The effect of a large shareholder on corporate value, Management Science 39, 1407-21.

Hwang, B.-H., and S. Kim, 2009, It pays to have friends, Journal of Financial Economics 93, 13858.

Jackson, S. B., T. J. Lopez, and A. L. Reitenga, 2008, Accounting fundamentals and CEO bonus compensation, Journal of Accounting and Public Policy 27, 374-93.

Jensen, M. C., and W. H. Meckling, 1976, Theory of the firm: Managerial behavior, agency costs and ownership structure, Journal of Financial Economics 3, 305-60.

Jensen, M. C., and K. J. Murphy, 1990, Performance pay and top-management incentives, Journal of Political Economy 98, 225-64.

Karpoff, J. M., 2001, The impact of shareholder activism on target companies: A survey of empirical findings, Working Paper, University of Washington.

Leone, A. J., J. S. Wu, and J. L. Zimmerman, 2006, Asymmetric sensitivity of CEO cash compensation to stock returns, Journal of Accounting and Economics 42, 167-92.

Liu, C., C. Y. Chung, H. K. Sul, and K. Wang, 2018, Does hometown advantage matter? The case of institutional blockholder monitoring on earnings management in Korea, Journal of International Business Studies 49(2), 196-221.

McCahery, J. A., Z. Sautner, and L. T. Starks, 2016, Behind the scenes: The corporate governance preferences of institutional investors, Journal of Finance 71, 2905-2932.McConaughy, D. L., and C. S. Mishra, 1996, Debt, performance-based incentives and firm performance, Financial Management 25, 37-51. 
McConnell, J., and H. Servaes, 1990, Additional evidence on equity ownership and corporate value, Journal of Financial Economics 27, 595-612.

Monks, R. A. G., and N. Minow, 2008, Corporate Governance (Blackwell Publishing, Oxford).

Mørck, R., A. Shleifer, and R. Vishny, 1988, Management ownership and market valuation: An empirical analysis, Journal of Financial Economics 20, 293-315.

Murphy, K. J., 1985, Corporate performance and managerial remuneration: An empirical analysis, Journal of Accounting and Economics 7, 3-36.

Murphy, K. J., 1999, Executive compensation, in O. Ashenfelter and D. Card, eds.: Handbook of Labor Economics (North Holland, Amsterdam), vol. 3, 2485-2563.

Murphy, K. J., 2013, Executive compensation: Where we are, and how we got there, in G. M. Constantinides, M. Harris, and R. M. Stulz, eds.: Handbook of the Economics of Finance (North Holland, Amsterdam), vol. 2, 211-356.

Newey, W. K., and K. D. West, 1987, A simple, positive semi-definite, heteroskedasticity and autocorrelation consistent covariance matrix, Econometrica 55, 703-08.

Newey, W. K., and K. D. West, 1994, Automatic lag selection in covariance matrix estimation, Review of Economic Studies 61, 631-54.

Ozkan, N., 2011, CEO compensation and firm performance: An empirical investigation of UK panel data, European Financial Management 17, 260-85.

Petersen, M. A., 2009, Estimating standard errors in finance panel data sets: Comparing approaches, Review of Financial Studies 22, 435-80.

Schaefer, S., 1998, The dependence of pay-performance sensitivity on the size of the firm, Review of Economics and Statistics 80, 436-43. 
Shaw, K. W., and M. H. Zhang, 2010, Is CEO cash compensation punished for poor firm performance? Accounting Review 85, 1065-93.

Shin, J. Y., and J. Seo, 2011, Less pay and more sensitivity? Institutional investor heterogeneity and CEO, Journal of Management 37, 1719-46.

Shin, T., 2013, Fair pay or power play? Pay equity, managerial power, and compensation adjustments for CEOs, Journal of Management 42, 419-48.

Shleifer, A., and R. W. Vishny, 1986, Large shareholders and corporate control, Journal of Political Economy 94, 461-78.

Shue, K., and R. R. Townsend, 2017, Growth through rigidity: An explanation for the rise in CEO pay, Journal of Financial Economics 123, 1-21.

Sloan, R., 1993, Accounting earnings and top executive compensation, Journal of Accounting and Economics 16, 55-100.

Smith, M. P., 1996, Shareholder activism by institutional investors: Evidence from CalPERS, Journal of Finance 51, 227-52.

Tobin, J., 1969, A general equilibrium approach to monetary theory, Journal of Money, Credit, and Banking 1, 15-29.

Woidtke, T., 2002, Agents watching agents? Evidence from pension fund ownership and firm value, Journal of Financial Economics 63, 99-131.

Yan, X., and Z. Zhang, 2009, Institutional investors and equity returns: Are short-term institutions better informed? Review of Financial Studies 22, 893-924.

Yermack, D., 1997, Good timing: CEO stock option awards and company news announcements, Journal of Finance 52, 449-76. 
TABLE 1. Descriptive Statistics.

\begin{tabular}{|c|c|c|c|c|c|}
\hline Variable & Mean & Std. Dev. & $\begin{array}{c}\text { First } \\
\text { Quartile }\end{array}$ & Median & $\begin{array}{c}\text { Third } \\
\text { Quartile }\end{array}$ \\
\hline \multicolumn{6}{|c|}{ Dependent variables } \\
\hline$\Delta P a y$ & 0.063 & 0.837 & -0.243 & 0.053 & 0.386 \\
\hline Return & 0.184 & 0.709 & -0.154 & 0.098 & 0.370 \\
\hline$Q$ & 2.078 & 1.755 & 1.239 & 1.621 & 2.325 \\
\hline \multicolumn{6}{|c|}{ Independent variables } \\
\hline$\triangle R O A$ & -0.015 & 0.904 & -0.285 & 0.009 & 0.248 \\
\hline$\Delta$ Assets & 0.106 & 0.234 & -0.003 & 0.072 & 0.174 \\
\hline$\Delta$ Sales & 0.093 & 0.249 & 0.003 & 0.083 & 0.177 \\
\hline$\Delta I \_R O A$ & 0.042 & 0.369 & -0.074 & 0.059 & 0.169 \\
\hline$C I$ & 6.119 & 50.425 & 0.638 & 2.107 & 6.012 \\
\hline$\Delta C I$ & -0.001 & 0.173 & -0.006 & 0.004 & 0.014 \\
\hline$I O$ & 0.675 & 0.192 & 0.555 & 0.703 & 0.822 \\
\hline SIO & 0.152 & 0.098 & 0.079 & 0.133 & 0.207 \\
\hline LIO & 0.205 & 0.095 & 0.136 & 0.194 & 0.261 \\
\hline$D D$ & 0.493 & 0.500 & 0.000 & 0.000 & 1.000 \\
\hline Rigidity & 0.526 & 0.499 & 0.000 & 1.000 & 1.000 \\
\hline
\end{tabular}

Note: This table summarizes the descriptive statistics of the dependent and independent variables of this study for the sample of 11,294 firm-year observations, excluding financial and utility firms, sourced from the Center for Research in Securities Prices, Compustat, ExecuComp, and Thomson Financial for 19952012. For each firm $i$ in year $t$, the dependent variables are $\Delta$ Pay, which is the rate of change in total executive compensation in terms of total yearly salaries, bonuses, long-term incentives, stock and option grants, and other compensation for up to five top-level executives, with at least two consecutive years of coverage; Return, which is the log of the fraction of the stock price over the previous year-end's price; and $Q$, which is industry-adjusted Tobin's $\mathrm{Q}$, computed as the market value of assets divided by the book value of assets. Refer to Appendix A for the definitions of the independent variables. 
TABLE 2. Pay for Performance Sensitivity.

Panel A. Pearson Correlation between $\triangle$ Pay and $\triangle$ Market Capitalization

\begin{tabular}{|c|c|c|c|c|}
\hline & \multicolumn{3}{|c|}{$\Delta$ Market Capitalization } \\
\hline & & Positive & Negative & Full \\
\hline$\Delta$ Market Capitalization & & $\begin{array}{r}0.108 * * * * \\
(.0000) \\
\end{array}$ & $\begin{array}{r}0.038 * * * * \\
(.0003) \\
\end{array}$ & $\begin{array}{r}0.084 * * * \\
(.0000) \\
\end{array}$ \\
\hline Panel B. Panel Regression Results & & & & \\
\hline Variable & Model 1 & Model 2 & Model 3 & Model 4 \\
\hline$\Delta$ Market Capitalization & $\begin{array}{r}0.108 * * * \\
(12.61)\end{array}$ & $\begin{array}{r}0.137 * * * \\
(12.44)\end{array}$ & $\begin{array}{r}0.053 * * * \\
(3.64)\end{array}$ & $\begin{array}{r}0.137 * * * \\
(11.56)\end{array}$ \\
\hline MC_Dummy & & & & $\begin{array}{r}-565.980 * * * \\
(-4.07)\end{array}$ \\
\hline$\Delta$ Market Capitalization $\times$ MC_Dummy & & & & $\begin{array}{r}-0.084 * * * \\
(-4.73)\end{array}$ \\
\hline Sign of $\Delta$ Market Capitalization & Full & Positive & Negative & Full \\
\hline No. of obs. & 22,132 & 13,153 & 8,979 & 22,132 \\
\hline Adj. $R^{2}$ & 0.007 & 0.012 & 0.001 & 0.009 \\
\hline
\end{tabular}

Note: This table is based on 22,132 raw firm-year observations for 1995-2012. Panel A presents the Pearson correlations between the changes in market capitalization (increases $(\Delta>0)$, decreases $(\Delta<0)$, and full sample) and the change in total executive pay $(\triangle P a y)$; the $p$-values are reported in parentheses. Panel B presents the panel regression results of the change in total executive compensation ( $\triangle$ Pay) on the change in market capitalization ( $\Delta$ Market Capitalization); the $t$-statistics (reported in parentheses) are adjusted for robust clustering (Petersen 2009). The coefficient of $\Delta$ Market Capitalization is the conventional measure of pay-for-performance sensitivity. MC_Dummy is a dummy variable equal to 1 if $\Delta$ Market Capitalization is lower than one, and 0 otherwise. $* * *$ Significant at the $1 \%$ level. 
TABLE 3. Executive Compensation Rigidity.

\begin{tabular}{|c|c|c|c|c|}
\hline Variable & Model 1 & Model 2 & Model 3 & Model 4 \\
\hline \multirow[t]{2}{*}{$\triangle R O A$} & $0.039 * * *$ & $0.027 * *$ & $0.047 * *$ & $0.040 * *$ \\
\hline & $(2.98)$ & $(2.08)$ & $(2.12)$ & $(1.62)$ \\
\hline \multirow[t]{2}{*}{$D D$} & $-0.142 * * *$ & $-0.138 * * *$ & $-0.124 * * *$ & $-0.111 * * *$ \\
\hline & $(-8.81)$ & $(-8.51)$ & $(-9.58)$ & $(-8.00)$ \\
\hline \multirow[t]{2}{*}{$\triangle R O A \times D D$} & $-0.047 * *$ & $-0.023 *$ & $-0.038 * *$ & $-0.022 *$ \\
\hline & $(-2.37)$ & $(-1.84)$ & $(-2.54)$ & $(-1.73)$ \\
\hline \multirow[t]{2}{*}{$\Delta$ Assets } & & $0.420 * * *$ & & $0.354 * * *$ \\
\hline & & $(9.99)$ & & $(8.39)$ \\
\hline \multirow[t]{2}{*}{$\Delta$ Sales } & & $0.119 * * *$ & & $0.103 * *$ \\
\hline & & $(2.89)$ & & $(2.90)$ \\
\hline \multirow[t]{2}{*}{$\Delta I \_R O A$} & & $0.179 * * *$ & & $0.598 * * *$ \\
\hline & & $(9.24)$ & & $(8.88)$ \\
\hline Panel regression & Yes & Yes & No & No \\
\hline Fama-MacBeth regression & No & No & Yes & Yes \\
\hline Year fixed effects & Yes & Yes & No & No \\
\hline Fama-French 48-industry fixed effects & Yes & Yes & Yes & Yes \\
\hline No. of obs. & 11,294 & 11,294 & 11,294 & 11,294 \\
\hline Adj. $R^{2}$ & 0.009 & 0.035 & 0.010 & 0.043 \\
\hline
\end{tabular}

Note: This table is based on 11,294 firm-year observations for 1995-2012. Models 1 and 2 present the panel regressions of the change in total executive compensation ( $\triangle P a y$ ), where the reported $t$-statistics (in parentheses) are adjusted for robust clustering, as per Petersen (2009). Models 3 and 4 provide FamaMacBeth (1973) regressions, where the reported $t$-statistics (in parentheses) are adjusted for autocorrelations with three lags, as per Newey and West $(1987,1994)$. The dependent variable is $\Delta$ Pay, which is the rate of change in total executive compensation in terms of total yearly salaries, bonuses, longterm incentives, stock and option grants, and other compensation for up to five top-level executives, with at least two consecutive years of coverage. Refer to Appendix A for the definitions of the independent variables. Please note that the intercepts are excluded from the presentation of the fixed effects regressions. $* * *$ Significant at the $1 \%$ level.

**Significant at the 5\% level.

*Significant at the $10 \%$ level. 
TABLE 4. Executive Compensation Rigidity and Firm Value.

\begin{tabular}{lrrrr}
\hline Variable & Model 1 & Model 2 & Model 3 & Model 4 \\
\hline$C I$ & 0.010 & $0.002^{* * *}$ & 0.001 & $0.009^{* *}$ \\
& $(1.45)$ & $(4.62)$ & $(0.69)$ & $(2.42)$ \\
$\Delta C I$ & $0.221^{* *}$ & $0.200^{* *}$ & $0.739^{* *}$ & $0.610^{* *}$ \\
Rigidity & $(2.37)$ & $(2.06)$ & $(2.08)$ & $(2.74)$ \\
& $-0.012^{* * *}$ & $-0.031^{* * *}$ & $-0.008^{*}$ & $-0.021^{* *}$ \\
Dependent variable & $(-3.07)$ & $(-2.89)$ & $(-1.89)$ & $(-2.19)$ \\
Panel regression & Return & $Q$ & Return & $Q$ \\
Fama-MacBeth regression & Yes & Yes & No & No \\
Full institutional ownership & No & No & Yes & Yes \\
Year fixed effects & Yes & No & Yes & No \\
Fama-French 48-industry fixed effects & Yes & Yes & No & No \\
No. of obs. & Yes & Yes & Yes & Yes \\
Adj. $R^{2}$ & 11,294 & 11,294 & 11,294 & 11,294 \\
\hline
\end{tabular}

Note: This table is based on firm-year observations for 1995-2012. Models 1 and 2 present the panel regression results, with $t$-statistics (in parentheses) adjusted for robust clustering, as per Petersen (2009). Models 3 and 4 provide the Fama and MacBeth (1973) regression results, with $t$-statistics (in parentheses) adjusted for autocorrelations with three lags, as per Newey and West $(1987,1994)$. For each firm $i$ in year $t$, the dependent variables are Return (models 1 and 3), which is the log of the fraction of the stock price over the previous year-end's price, and $Q$ (models 2 and 4), which is the industry-adjusted Tobin's Q, computed as the market value of assets divided by the book value of assets. Refer to Appendix A for the definitions of the independent variables. Please note that the intercepts are excluded from the presentation of the fixed effects regressions.

$* * *$ Significant at the $1 \%$ level.

**Significant at the 5\% level.

*Significant at the $10 \%$ level. 
TABLE 5. Executive Compensation Rigidity by Institutional Investor Group.

\begin{tabular}{lrrrrrr}
\hline Institutions & $\mathrm{Q} 1$ & $\mathrm{Q} 2$ & $\mathrm{Q} 3$ & $\mathrm{Q} 4$ & $\mathrm{Q} 5$ & $\mathrm{Q} 5-\mathrm{Q} 1$ \\
\hline All (IO) & 0.391 & 0.324 & 0.306 & 0.288 & 0.259 & -0.131 \\
& & & & & & $(-2.88)^{* * *}$ \\
Long-term (LIO) & 0.521 & 0.498 & 0.470 & 0.382 & 0.216 & -0.305 \\
& & & & & & $(-3.23)^{* * *}$ \\
Short-term (SIO) & 0.435 & 0.389 & 0.392 & 0.402 & 0.411 & -0.024 \\
& & & & & & -1.34 \\
\hline
\end{tabular}

Note: In this table, we sort the sample firms in ascending order of executive compensation rigidity (ECR) into five quintile groups for ownership by all (IO), long-term (LIO), and short-term (SIO) institutions, where SIO (LIO) denotes institutional ownership by short-term (long-term) institutions, as per Yan and Zhang's (2009) churn rate. Rigidity (ECR) is a dummy variable equal to 1 if the time-series regression estimate for the interaction term of the change in return on assets (ROA) and the ROA dummy variable $\left(\triangle R O A_{i t} \times D D_{i t}\right)$ in equation (2) is less than or equal to zero, and 0 otherwise, where the dependent variable is the change in total executive compensation $(\triangle P a y)$. The differences between the mean values of ECR of the largest quintile firm and the lowest quintile firms are provided in the last column, where the $t$ statistics are provided in parentheses.

*** Significant at the $1 \%$ level. 
TABLE 6. Impacts of Institutional Monitoring on Executive Compensation.

\begin{tabular}{|c|c|c|c|c|}
\hline Variable & Model 1 & Model 2 & Model 3 & Model 4 \\
\hline \multirow[t]{2}{*}{$\triangle R O A$} & $0.017 * * *$ & $0.025^{*}$ & $0.085^{* *}$ & $0.130 *$ \\
\hline & $(3.07)$ & $(1.89)$ & $(2.07)$ & $(1.79)$ \\
\hline \multirow[t]{2}{*}{$D D$} & $-0.213 * * *$ & $-0.217 * * *$ & $-0.172 * *$ & $-0.164 * * *$ \\
\hline & $(-3.74)$ & $(-4.35)$ & $(-2.39)$ & $(-2.86)$ \\
\hline \multirow[t]{2}{*}{$\triangle R O A \times D D$} & $-0.081 * * *$ & $-0.089 * * *$ & $-0.171^{*}$ & $-0.192 *$ \\
\hline & $(-3.89)$ & $(-2.84)$ & $(-1.89)$ & $(-1.69)$ \\
\hline \multirow[t]{2}{*}{$I O$} & 0.025 & & 0.070 & \\
\hline & $(0.44)$ & & $(1.23)$ & \\
\hline \multirow[t]{2}{*}{$\triangle R O A \times D D \times I O$} & $0.125^{*}$ & & $0.501 *$ & \\
\hline & $(1.83)$ & & $(1.71)$ & \\
\hline \multirow[t]{2}{*}{ SIO } & & 0.029 & & -0.183 \\
\hline & & $(0.24)$ & & $(-0.84)$ \\
\hline \multirow[t]{2}{*}{$\triangle R O A \times D D \times S I O$} & & 0.132 & & -0.369 \\
\hline & & $(0.68)$ & & $(-1.15)$ \\
\hline \multirow[t]{2}{*}{$L I O$} & & 0.123 & & 0.343 \\
\hline & & (1.04) & & $(1.01)$ \\
\hline \multirow[t]{2}{*}{$\triangle R O A \times D D \times L I O$} & & $0.370 * *$ & & $0.597 * *$ \\
\hline & & $(1.98)$ & & $(2.64)$ \\
\hline \multirow[t]{2}{*}{$\Delta$ Assets } & $0.417 * * *$ & $0.412 * * *$ & $0.336 * * *$ & $0.292 * * *$ \\
\hline & $(9.92)$ & $(9.63)$ & $(6.68)$ & $(3.40)$ \\
\hline \multirow[t]{2}{*}{$\Delta$ Sales } & $0.119 * * *$ & $0.118 * * *$ & 0.054 & $0.099 * * *$ \\
\hline & $(-2.87)$ & $(2.84)$ & $(1.14)$ & $(3.04)$ \\
\hline \multirow[t]{2}{*}{$\Delta I \_R O A$} & $0.179 * * *$ & $0.180 * * *$ & $0.601 * * *$ & $0.600 * * *$ \\
\hline & $(9.23)$ & $(9.29)$ & $(8.84)$ & $(8.76)$ \\
\hline Panel regression & Yes & Yes & No & No \\
\hline Fama-MacBeth regression & No & No & Yes & Yes \\
\hline Year fixed effects & Yes & Yes & No & No \\
\hline $\begin{array}{l}\text { Fama-French } 48 \text {-industry } \\
\text { fixed effects }\end{array}$ & Yes & Yes & Yes & Yes \\
\hline No. of obs. & 11,294 & 11,294 & 11,294 & 11,294 \\
\hline Adj. $R^{2}$ & 0.036 & 0.036 & 0.053 & 0.051 \\
\hline
\end{tabular}

Note: This table is based on firm-year observations for 1995-2012. Models 1 and 2 present the panel regressions of the change in total executive compensation $(\triangle P a y)$, where the reported $t$-statistics (in parentheses) are adjusted for robust clustering, as per Petersen (2009). Models 3 and 4 provide the FamaMacBeth (1973) regressions, where the reported $t$-statistics (in parentheses) are adjusted for autocorrelations with three lags, as per Newey and West $(1987,1994)$. For each firm $i$ in year $t$, the dependent variable is $\triangle$ Pay, which is the rate of change in total executive compensation in terms of total yearly salaries, bonuses, long-term incentives, stock and option grants, and other compensation for up to five top-level executives, with at least two consecutive years of coverage. Refer to Appendix A for the definitions of the independent variables. Please note that the intercepts are excluded from the presentation of the fixed effects regressions.

$* * *$ Significant at the $1 \%$ level.

**Significant at the 5\% level. 
*Significant at the $10 \%$ level. 
TABLE 7. Institutional Monitoring, Executive Compensation Rigidity, and Firm Value.

\begin{tabular}{|c|c|c|c|c|c|c|c|c|}
\hline Variable & Model 1 & Model 2 & Model 3 & Model 4 & Model 5 & Model 6 & Model 7 & Model 8 \\
\hline$C I$ & $\begin{array}{c}0.021 * * \\
(2.07)\end{array}$ & $\begin{array}{c}0.002^{* * *} \\
(4.58)\end{array}$ & $\begin{array}{l}0.015^{*} \\
(1.79)\end{array}$ & $\begin{array}{c}0.002 * * * \\
(6.24)\end{array}$ & $\begin{array}{l}0.002 \\
(1.07)\end{array}$ & $\begin{array}{c}0.009 * * \\
(2.46)\end{array}$ & $\begin{array}{l}0.001 \\
(0.78)\end{array}$ & $\begin{array}{c}0.011 * * \\
(2.45)\end{array}$ \\
\hline$\Delta C I$ & $\begin{array}{c}0.146^{* *} \\
(2.23)\end{array}$ & $\begin{array}{c}0.203^{* *} \\
(2.09)\end{array}$ & $\begin{array}{c}0.240 * * \\
(2.34)\end{array}$ & $\begin{array}{l}0.166^{*} \\
(1.72)\end{array}$ & $\begin{array}{c}0.720 * * \\
(2.21)\end{array}$ & $\begin{array}{c}0.660 * * \\
(2.84)\end{array}$ & $\begin{array}{c}0.563^{* *} \\
(2.34)\end{array}$ & $\begin{array}{c}0.388^{* *} \\
(2.50)\end{array}$ \\
\hline Rigidity & $\begin{array}{c}-0.033 * * \\
(-3.43)\end{array}$ & $\begin{array}{c}-0.057 * * \\
(-2.17)\end{array}$ & $\begin{array}{c}-0.018 * * * \\
(-2.84)\end{array}$ & $\begin{array}{l}-0.018^{*} \\
(-1.89)\end{array}$ & $\begin{array}{c}-0.019 * * \\
(-2.43)\end{array}$ & $\begin{array}{c}-0.080^{*} \\
(-1.83)\end{array}$ & $\begin{array}{c}-0.010^{*} \\
(-1.74)\end{array}$ & $\begin{array}{l}-0.123 * \\
(-1.73)\end{array}$ \\
\hline IO & $\begin{array}{c}0.083^{*} \\
(1.73)\end{array}$ & $\begin{array}{c}-0.264 * * \\
(-2.23)\end{array}$ & & & $\begin{array}{l}0.122 \\
(1.51)\end{array}$ & $\begin{array}{c}0.292 * * \\
(2.24)\end{array}$ & & \\
\hline Rigidity $\times I O$ & $\begin{array}{r}0.032^{*} \\
(1.73)\end{array}$ & $\begin{array}{c}0.036^{* * *} \\
(2.13)\end{array}$ & & & $\begin{array}{l}0.023 \\
(0.73)\end{array}$ & $\begin{array}{c}0.032 * \\
(1.93)\end{array}$ & & \\
\hline SIO & & & $\begin{array}{c}1.331 * * * \\
(14.29)\end{array}$ & $\begin{array}{c}1.979 * * * \\
(8.53)\end{array}$ & & & $\begin{array}{c}1.133 * * * \\
(5.10)\end{array}$ & $\begin{array}{c}2.015 * * * \\
(3.14)\end{array}$ \\
\hline Rigidity $\times$ SIO & & & $\begin{array}{r}-0.014^{*} \\
(-1.88)\end{array}$ & $\begin{array}{r}-0.1179 \\
(-0.98)\end{array}$ & & & $\begin{array}{l}0.055 \\
(0.78)\end{array}$ & $\begin{array}{c}-0.2823 \\
(-0.60)\end{array}$ \\
\hline LIO & & & $\begin{array}{c}-0.345^{* * * *} \\
(-3.55)\end{array}$ & $\begin{array}{c}-1.589 * * * \\
(-6.57)\end{array}$ & & & $\begin{array}{c}-0.269 * * \\
(-2.54)\end{array}$ & $\begin{array}{c}-0.754 * * * \\
(-2.96)\end{array}$ \\
\hline Rigidity $\times$ LIO & & & $\begin{array}{r}0.076^{*} \\
(1.87)\end{array}$ & $\begin{array}{c}0.117 * * \\
(2.15)\end{array}$ & & & $\begin{array}{c}0.02 \\
(1.13)\end{array}$ & $\begin{array}{l}0.132^{*} \\
(1.83)\end{array}$ \\
\hline Dependent variable & Return & $Q$ & Return & $Q$ & Return & $Q$ & Return & $Q$ \\
\hline Panel regression & Yes & Yes & Yes & Yes & No & No & No & No \\
\hline $\begin{array}{l}\text { Fama-MacBeth } \\
\text { regression }\end{array}$ & No & No & No & No & Yes & Yes & Yes & Yes \\
\hline Year fixed effects & Yes & Yes & Yes & Yes & No & No & No & No \\
\hline $\begin{array}{l}\text { Fama-French industry } \\
\text { fixed effects }\end{array}$ & Yes & Yes & Yes & Yes & Yes & Yes & Yes & Yes \\
\hline No. of obs. & 11,294 & 11,294 & 11,294 & 11,294 & 11,294 & 11,294 & 11,294 & 11,294 \\
\hline Adj. $R^{2}$ & 0.005 & 0.003 & 0.04 & 0.023 & 0.044 & 0.001 & 0.085 & 0.020 \\
\hline
\end{tabular}

Note: This table is based on firm-year observations for 1995-2012. Models 1-4 present the panel regression results, with $t$-statistics (reported in parentheses) adjusted for robust clustering, as per Petersen (2009). Models 5-8 provide the Fama-MacBeth (1973) regression results, with $t$-statistics (reported in parentheses) adjusted for autocorrelations with three lags, as per Newey and West $(1987,1994)$. For each firm $i$ in year $t$, the dependent variables are Return (models 1, 3, 5, and 7), which is the log of the fraction of the stock price over the previous year-end's price, and $Q$ (models 2, 4, 6, and 8), which is industry-adjusted Tobin's $\mathrm{Q}$, computed as the market value of assets divided by the book value of assets. Refer to Appendix A for the definitions of the independent variables. Please note that the intercepts are excluded from the presentation of the fixed effects regressions.

***Significant at the $1 \%$ level.

**Significant at the 5\% level.

*Significant at the $10 \%$ level. 
Appendix A: Variable Definitions

\begin{tabular}{|c|c|}
\hline Variable & Definition \\
\hline \multicolumn{2}{|c|}{ Dependent variables } \\
\hline$\triangle P a y$ & $\begin{array}{l}\text { Rate of change in total executive compensation in terms of total yearly salaries, bonuses, long- } \\
\text { term incentives, stock and option grants, and other compensation for up to five top-level } \\
\text { executives, with at least two consecutive years of coverage. }\end{array}$ \\
\hline Return & Log of the fraction of the stock price over the previous year-end's price. \\
\hline$Q$ & $\begin{array}{l}\text { Industry-adjusted Tobin's Q, computed as the market value of assets divided by the book value } \\
\text { of assets. }\end{array}$ \\
\hline \multicolumn{2}{|c|}{ Independent variables } \\
\hline$\triangle R O A$ & Natural logarithm of the ratio of return on assets (ROA) to lagged ROA. \\
\hline$\Delta$ Asset & Natural logarithm of the ratio of the book value of assets to the lagged book value of assets. \\
\hline$\Delta$ Sale & Natural logarithm of the ratio of sales to lagged sales. \\
\hline$\Delta I \_R O A$ & Industry average of the natural logarithm of the ratio of ROA to lagged ROA. \\
\hline$C I$ & $\begin{array}{l}\text { Comprehensive income (CI), normalized by the stock price at the end of the previous year } \\
\text { (Easton and Pae 2004). }\end{array}$ \\
\hline$\Delta C I$ & $\begin{array}{l}\text { Ratio of CI to lagged CI for firm } i \text { in year } t \text {, normalized by the stock price at the end of the } \\
\text { previous year. }\end{array}$ \\
\hline$I O$ & $\begin{array}{l}\text { Total institutional ownership, computed as the number of shares held by all institutions divided } \\
\text { by the shares outstanding in the previous year. }\end{array}$ \\
\hline $\mathrm{SIO}$ & Institutional ownership by short-term institutions, as per Yan and Zhang's (2009) churn rate. \\
\hline$L I O$ & $\begin{array}{l}\text { Institutional ownership by long-term institutions, as per Yan and Zhang's (2009) churn } \\
\text { rate. }\end{array}$ \\
\hline MON5 & $\begin{array}{l}\text { Proportion of ownership by monitoring institutional investors as the fraction of shares } \\
\text { outstanding owned by the five largest institutions. According to Bushee (2001), an } \\
\text { institutional investor is classified as one of the five largest institutions if the institution is } \\
\text { (1) one of the five institutions with the largest portfolio valuations (in U.S. dollars) at the } \\
\text { end of the quarter, (2) one of the five largest institutions for the past year, and (3) a dedicated } \\
\text { or quasi-indexer institution. }\end{array}$ \\
\hline Non-MON5 & $\begin{array}{l}\text { Proportion of ownership of shares outstanding by (non)monitoring institutional investors } \\
\text { other than the five largest institutions, as per Bushee (2001). }\end{array}$ \\
\hline$D D$ & $\begin{array}{l}\text { Dummy variable equal to } 1 \text { if ROA is lower than the previous year's ROA, and } 0 \\
\text { otherwise. }\end{array}$ \\
\hline Rigidity & $\begin{array}{l}\text { Dummy variable as a proxy for executive compensation rigidity equal to } 1 \text { if the time- } \\
\text { series regression estimate of the interaction term for the change in ROA and the ROA } \\
\left.\text { dummy variable ( } \triangle R O A_{i t} \times D D_{i t}\right) \text { in equation (2) is less than or equal to zero, and } 0 \\
\text { otherwise. Here, we control for } \triangle A \text { ssets, } \triangle \text { Sales, } \triangle I \_R O A \text {, and year, as well as Fama and } \\
\text { French's (1997) } 48 \text {-industry fixed effects: }\end{array}$ \\
\hline & $\Delta$ Pay $_{i t}=\beta_{0}+\beta_{1} \Delta R O A_{i t}+\beta_{2} D D_{i t}+\beta_{3} \Delta R O A_{i t} \times D D_{i t}+\sum \beta_{c}$ Controls $_{i t}+\epsilon_{i t}$ \\
\hline
\end{tabular}


Note: This appendix provides definitions of the variables for each firm $i$ in year $t$. Firm characteristics are obtained from the Center for Research in Security Prices and Compustat databases, executive compensation is taken from ExecuComp, and institutional ownership is taken from Thomson Financial for 1995-2012. The industry of a firm is classified as per Fama and French's (1997) 48-industry classification. The final sample consists of 11,294 firm-year observations, excluding financial and utility firms. 


\section{Appendix B: Robustness Tests}

Chen, Harford, and Li (2007) and Chung et al. (2015) document that not all long-term institutions have the incentives or means to monitor firm management. Instead, they find that only independent, long-term institutions with large shareholdings focus on monitoring and influencing the firms in which they invest. We follow these studies by adopting an alternative measure of monitoring institutions' holdings, defined as the proportion of ownership by the five largest institutions (MON5). Consequently, the ownership by all other institutions (Non_MON5) is considered to be held by nonmonitoring institutions. ${ }^{13}$ According to Bushee (2001), an institutional investor is classified as one of the five largest institutions if the institution (1) has one of the five largest holdings (in U.S. dollars) of stock at the end of a quarter and for the past year, and (2) is a dedicated or quasi-indexer institution. These institutions are more likely to perform a monitoring role by gathering information and attempting to influence managers.

We replicate the tests in Table 6, based on equation (4), by replacing the ownership measures of all $(I O)$, long-term $(L I O)$, and short-term $(S I O)$ institutional investors with the alternative measures (MON5 and Non_MON5), and present the results in Table B1. We find that

\footnotetext{
${ }^{13}$ The alternative measures provide the benefit of further considering the influence of institutional investors with large blockholdings. However, when it comes to capturing the factor differentiating between investors' investments and monitoring incentives based on investment horizon (Chen, Harford, and Li 2007; Chung et al. 2015; Yan and Zhang 2009), the alternatives are not as sophisticated as the main measures, SIO and LIO. Hence, the robustness tests with the alternative measures complement our main tests based on SIO and LIO. In addition to Non_MON5 and MON5, motivated by Hadlock and Schwartz-Ziv (2018), we consider the classification of institutional blockholding based on Chen, Harford, and Li (2007), which includes all institutional investors that (1) hold at least $5 \%$ of the shares outstanding (blockholders) at the end of the current quarter, (2) hold at least 5\% of the shares outstanding for the past year, and (3) are classified as a dedicated or quasi-indexing institution using Bushee's (2001) definitions. We find that the institutional blockholders mitigate the downward pay rigidity of top managers and facilitate value creation in a firm. The results are available upon request.
} 
the coefficient of the three-way interaction term $\triangle R O A \times D D \times M O N 5$ using either a panel (model 1) or a Fama-MacBeth (1973) (model 2) regression of the change in executive pay $(\Delta P a y)$ is positive and significant in economic and statistical terms $\left(\hat{\beta}_{5}>0\right)$. This implies that long-term institutional investors with large shareholdings actively reduce the extent of the pay rigidity. The literature suggests that the stronger elasticity of pay-performance induced by monitoring blockholders reveals the alignment of the interests of managers and shareholders (Ozkan 2011). Our robustness check supports Hypothesis H2a, as well as the claim by Bebchuk and Fried (2003, 2004) that monitoring blockholders control pay without performance, thus lowering agency costs.

[Insert Table B1 about here.]

To further stress test Hypothesis $\mathrm{H} 2 \mathrm{~b}$, we reexamine whether institutional monitoring on pay without performance offers benefits to shareholders by reconstructing Table 7 using the alternative measures of institutional ownership (MON5 and Non_MON5). The results are shown in Table B2. In terms of stock returns (models 1 and 3) or Tobin's Q (models 2 and 4), both the panel (models 1 and 2) and Fama-MacBeth (1973) (models 3 and 4) regressions show that the downward rigidity of executive pay (Rigidity) is value destroying $\left(\hat{\beta}_{3}<0\right)$, but also that nonmonitoring institutional investors do not contribute to curbing the pay distortion $\left(\hat{\beta}_{4}<0\right.$, Rigidity $\times$ Non_MON5). In contrast, the five largest institutional investors in terms of holdings appear to resist the value-eroding executive compensation rigidity $\left(\hat{\beta}_{4}>0\right.$, Rigidity $\times$ MON5). The strongest evidence is found when Tobin's Q is used to measure firm performance and the Fama-MacBeth method is used for the estimation (model 4). Overall, these results support the inference drawn previously from Table 7 related to Hypothesis H2b. That is, the monitoring activities of committed institutional investors mitigate the downward pay rigidity of top managers and facilitate value creation in a firm. 
[Insert Table B2 about here.] 
TABLE B1. Impacts of Institutional Monitoring on Executive Compensation with an Alternative Institutional Monitoring Measure.

\begin{tabular}{|c|c|c|}
\hline Variable & Model 1 & Model 2 \\
\hline \multirow[t]{2}{*}{$\triangle R O A$} & $0.018 * * *$ & $0.079 * *$ \\
\hline & $(2.89)$ & $(2.39)$ \\
\hline \multirow{2}{*}{$D D$} & $-0.113 * *$ & $-0.112 *$ \\
\hline & $(-2.35)$ & $(-1.86)$ \\
\hline \multirow[t]{2}{*}{$\triangle R O A \times D D$} & $-0.129 * *$ & $-0.235 * *$ \\
\hline & $(-2.18)$ & $(-2.68)$ \\
\hline \multirow[t]{2}{*}{ Non_MON5 } & -0.008 & 0.022 \\
\hline & $(-0.13)$ & $(0.63)$ \\
\hline \multirow[t]{2}{*}{$\triangle R O A \times D D \times N o n \_M O N 5$} & $-0.165^{*}$ & $-0.235 * * *$ \\
\hline & $(-2.58)$ & $(-2.95)$ \\
\hline \multirow[t]{2}{*}{ MON5 } & $0.200^{*}$ & 0.042 \\
\hline & $(1.70)$ & $(0.25)$ \\
\hline \multirow[t]{2}{*}{$\triangle R O A \times D D \times M O N 5$} & $0.290 * * *$ & $0.624 * * *$ \\
\hline & (3.14) & (3.13) \\
\hline \multirow[t]{2}{*}{$\Delta$ Asset } & $0.343 * * *$ & $0.126 * * *$ \\
\hline & $(4.54)$ & (3.87) \\
\hline \multirow[t]{2}{*}{$\Delta$ Sale } & $0.235 * * *$ & $0.199 * * *$ \\
\hline & $(3.32)$ & $(5.34)$ \\
\hline \multirow[t]{2}{*}{$\Delta I \_R O A$} & $0.176^{* * *}$ & $0.464 * * *$ \\
\hline & $(5.17)$ & $(7.11)$ \\
\hline Panel regression & Yes & No \\
\hline Fama-MacBeth regression & No & Yes \\
\hline Year fixed effects & Yes & No \\
\hline Fama-French 48-industry fixed effects & Yes & Yes \\
\hline No. of obs. & 11,294 & 11,294 \\
\hline Adj. $R^{2}$ & 0.057 & 0.087 \\
\hline
\end{tabular}

Note: This table is based on 11,294 firm-year observations for 1995-2012. Models 1 and 2 present the panel and Fama-MacBeth (1973) regressions of the change in total executive compensation $(\triangle P a y)$, where the reported $t$ statistics (in parentheses) are adjusted for robust clustering, as per Petersen (2009), and for autocorrelations with three lags, as per Newey and West $(1987,1994)$, respectively. The dependent variable is $\triangle$ Pay, which is the rate of change in total executive compensation in terms of total yearly salaries, bonuses, long-term incentives, stock and option grants, and other compensation for up to five top-level executives, with at least two consecutive years of coverage. Refer to Appendix A for the definitions of the independent variables. Please note that the intercepts are excluded from the presentation of the fixed effects regressions.

$* * *$ Significant at the $1 \%$ level.

**Significant at the $5 \%$ level.

* Significant at the $10 \%$ level. 
TABLE B2. Impacts of Executive Compensation Rigidity on Firm Value with an Alternative Institutional Monitoring Measure.

\begin{tabular}{lrrrr}
\hline Variable & Model 1 & Model 2 & Model 3 & Model 4 \\
\hline$C I$ & $0.024^{* *}$ & 0.012 & $0.032^{* *}$ & $0.019 * *$ \\
& $(2.39)$ & $(1.24)$ & $(2.39)$ & $(2.24)$ \\
$\Delta C I$ & $0.124^{*}$ & $0.233^{* *}$ & $0.124^{* * *}$ & $0.098^{* *}$ \\
& $(1.89)$ & $(2.13)$ & $(3.34)$ & $(2.52)$ \\
Rigidity & $-0.215^{* * *}$ & $-0.071 * *$ & $-0.025^{* * *}$ & -0.010 \\
& $(-3.86)$ & $(-2.59)$ & $(-3.84)$ & $(-0.78)$ \\
Non_MON5 & $1.331^{* * *}$ & $1.979 * * *$ & $1.354^{* * *}$ & $1.890^{* * *}$ \\
& $(14.29)$ & $(8.53)$ & $(5.39)$ & $(3.19)$ \\
Rigidity $\times$ Non_MON5 & $-0.129^{* * *}$ & $-0.077 *$ & $-0.014 * *$ & $-0.099 * *$ \\
& $(2.98)$ & $(-1.88)$ & $(-2.28)$ & $(-2.48)$ \\
MON5 & $-0.345^{* * *}$ & $-1.589 * * *$ & $-0.310 * *$ & $-0.978^{* *}$ \\
Rigidity $\times$ MON5 & $(-3.55)$ & $(-6.57)$ & $(-2.18)$ & $(-2.66)$ \\
& 0.055 & 0.088 & 0.021 & $0.077 * *$ \\
Dependent variable & $(1.67)$ & $(1.15)$ & $(0.36)$ & $(2.25)$ \\
Panel regression & Return & $Q$ & Return & $Q$ \\
Fama-MacBeth regression & Yes & Yes & No & No \\
Year fixed effects & No & No & Yes & Yes \\
Fama-French 48-industry fixed & Yes & Yes & No & No \\
effects & Yes & Yes & Yes & Yes \\
Adj. $R^{2}$ & 11,294 & 11,294 & 11,294 & 11,294 \\
\hline Nof obs. & 0.054 & 0.035 & 0.076 & 0.045 \\
\hline
\end{tabular}

Note: This table is based on 11,294 firm-year observations for 1995-2012. Models 1 and 2 present the panel regression results, with $t$-statistics (reported in parentheses) adjusted for robust clustering, as per Petersen (2009). Models 3 and 4 provide the Fama and MacBeth (1973) regression results, with $t$-statistics (reported in parentheses) adjusted for autocorrelations with three lags, as per Newey and West $(1987,1994)$. For each firm $i$ in year $t$, the dependent variables are Return (models 1 and 3), which is the log of the fraction of the stock price over the previous year-end's price, and $Q$ (models 2 and 4), which is industry-adjusted Tobin's $\mathrm{Q}$, computed as the market value of assets divided by the book value of assets. Refer to Appendix A for the definitions of the independent variables. Please note that the intercepts are excluded from the presentation of the fixed effects regressions.

$* * *$ Significant at the $1 \%$ level.

**Significant at the 5\% level.

*Significant at the $10 \%$ level. 


\section{Appendix C: Institutional Investors' Presence on the Board of Directors}

A common question that applies to most studies using institutional ownership as a proxy for institutional monitoring is what specific channels institutional investors use to achieve desired governance outcomes. In this section, we examine one such channel. Specifically, we identify directors directly employed by institutional investors and see whether these directors reduce downward ECR. Boards are the apex of corporate governance and have the fiduciary duty to deter managerial rent-seeking and maximize shareholder wealth. By sitting on a board, institutional investors gain access to the internal governance that gives them a substantial voice in corporate decisions. It is well known that activist shareholders often attempt to gain board representation to influence the management (DeAngelo and DeAngelo, 1989) and activist institutional investors prefer private communications with the management over open confrontations when they identify potential problems to address (Carleton, Nelson, and Weisbach, 1998; Becht, Franks, Mayer, and Rossi, 2009; McCahery, Sautner, and Starks, 2016). Our approach focuses on one of the most effective ways for institutional investors to influence corporate decisions and allows us to capture their private monitoring efforts.

[Insert Table C1 about here.]

We focus on two measures of institutional directors. The first is the number of institutional directors on the board and the second is a dummy variable indicating the presence of institutional directors. In Table C1, we show the correlations between these measures and our institutional ownership variables and find that the aggregate level of institutional ownership is positively related to both the number of institutional directors and the institutional director dummy. When we separate the aggregate institutional shareholdings into portions held by long-term and short-term institutions, we find that the positive relations are driven by the holdings of long-term institutions, suggesting that they are more likely to sit on the board to influence firm decisions. On the other 
hand, the correlations between short-term institutional ownership and the institutional director measures, although positive, are not statistically significant.

\section{[Insert Table C2 about here.]}

In Table C2, we examine the impact of institutional directors on the downward pay rigidity of CEOs using panel regressions with Petersen's (2009) clustering-robust standard errors. The model specifications are similar to those in Table 6. Using either the number of institutional directors or the institutional director dummy, we find that the three-way interaction term

Institutional Director Dummy, respectively) is statistically positive. Given the presence of pay rigidity as indicated by the significantly positive coefficient for the two-way interaction term $(\triangle R O A \times D D)$, these results provide strong evidence that institutional investors successfully reduce downward pay rigidity through their board presence.

We understand there are other possible channels through which institutional investors may affect executive compensation, such as sponsoring "say-on-pay" campaigns. However, we defer investigating these channels to future studies due to the scope of this research. 


\section{Table C1. Correlations}

\begin{tabular}{|c|c|c|c|c|c|}
\hline & IO & SIO & LIO & $\begin{array}{c}\text { \# of Institutional } \\
\text { Directors }\end{array}$ & $\begin{array}{c}\text { Institutional Director } \\
\text { Dummy }\end{array}$ \\
\hline $\mathrm{IO}$ & 1 & & & & \\
\hline SIO & $\begin{array}{c}0.4752 \\
{[<.0001]}\end{array}$ & 1 & & & \\
\hline LIO & $\begin{array}{c}0.4576 \\
{[<.0001]}\end{array}$ & $\begin{array}{l}-0.2188 \\
{[0.0117]}\end{array}$ & 1 & & \\
\hline $\begin{array}{l}\text { \# of Institutional } \\
\text { Directors }\end{array}$ & 0.0281 & 0.0649 & 0.1398 & 1 & \\
\hline \multirow{3}{*}{$\begin{array}{l}\text { Institutional Director } \\
\text { Dummy }\end{array}$} & {$[0.0891]$} & [0.4592] & {$[0.0398]$} & & \\
\hline & 0.0582 & 0.0485 & 0.1145 & 0.9216 & \multirow[t]{2}{*}{1} \\
\hline & {$[0.0472]$} & [0.5807] & {$[0.0191]$} & {$[<.0001]$} & \\
\hline
\end{tabular}

Notes: This table presents the Pearson correlation coefficients between institutional ownerships and institutional director variables based on 7,145 firm-year observations of S\&P 1500 firms for the period 1998-2012.; $p$-values are reported in brackets. 


\section{Table C2. Impacts of institutional monitoring on executive compensation with \# of institutional directors and institutional director dummy}

This table is based on 7,145 firm-year observations of S\&P 1500 firms for the period 1998-2012. Models 1 and 2 present the panel and Fama and MacBeth (1973) regressions of the change in total executive compensation ( $\triangle$ Pay), where the reported $t$-statistics (in parentheses) are adjusted for robust clustering per Petersen (2009). As the dependent variable, $\Delta$ Pay is the rate of change in total executive compensation in terms of total yearly salaries, bonuses, long-term incentives, stock and option grants, and other compensation for up to five top-level executives, with at least two consecutive years of coverage. Refer to Table A1 for the definitions of the independent variables. The intercepts are subdued with fixed effects. ***, **, and * indicate statistical significance at the $1 \%, 5 \%$, and $10 \%$ levels, respectively.

\begin{tabular}{|c|c|c|}
\hline Variable & Model 1 & Model 2 \\
\hline$\triangle \mathrm{ROA}$ & $\begin{aligned} 0.072 * \\
(1.91)\end{aligned}$ & $\begin{array}{r}0.063 * * \\
(2.15)\end{array}$ \\
\hline $\mathrm{DD}$ & $\begin{array}{r}-0.213 * * \\
(-2.33)\end{array}$ & $\begin{array}{r}-0.093^{*} \\
(-1.98)\end{array}$ \\
\hline$\triangle \mathrm{ROA} \times \mathrm{DD}$ & $\begin{array}{r}-0.271^{* *} \\
(-2.27)\end{array}$ & $\begin{array}{r}-0.153 * * \\
(-2.52)\end{array}$ \\
\hline Number of Institutional Directors & $\begin{array}{r}0.008 \\
(0.13)\end{array}$ & \\
\hline$\triangle \mathrm{ROA} \times \mathrm{DD} \times$ Number of Institutional Directors & $\begin{array}{r}0.239 * * \\
(2.48)\end{array}$ & \\
\hline Institutional Director Dummy & & $\begin{array}{r}0.042 \\
(0.25)\end{array}$ \\
\hline$\Delta \mathrm{ROA} \times \mathrm{DD} \times$ Institutional Director Dummy & & $\begin{array}{r}0.314 * * \\
(2.20)\end{array}$ \\
\hline$\Delta$ Asset & $\begin{array}{r}0.929 * * * \\
(3.07)\end{array}$ & $\begin{array}{r}0.135^{* * *} \\
(2.79)\end{array}$ \\
\hline$\Delta$ Sale & $\begin{array}{r}0.009^{* *} \\
(2.46)\end{array}$ & $\begin{array}{r}0.012 * * \\
(2.42)\end{array}$ \\
\hline$\Delta \mathrm{I} \_\mathrm{ROA}$ & $\begin{array}{r}0.659^{* *} \\
(2.84)\end{array}$ & $\begin{array}{r}0.309 * * \\
(2.74)\end{array}$ \\
\hline Panel regression & Yes & No \\
\hline Fama-MacBeth regression & No & Yes \\
\hline Year fixed effects & Yes & No \\
\hline Fama-French 48 industry fixed effects & Yes & Yes \\
\hline No. of obs. & 7,145 & 7,145 \\
\hline Adjusted-R ${ }^{2}$ & 0.124 & 0.176 \\
\hline
\end{tabular}

